\title{
MODELLING AND SIMULATION OF METHANOL PRODUCTION FROM COKE OVEN GAS
}

\author{
LETITIA PETRESCU ${ }^{a *}$, DUMITRITA-AURA CRISAN ${ }^{a}$
}

\begin{abstract}
Coke Oven Gas (COG) is highly rated as a valuable by-product of coke production used in the steel industry. The production of methanol from COG-derived syngas has been investigated in the last period due to its practicality as well as to the recent interest in methanol over the past years. Two case studies, using $\mathrm{COG}$ and $\mathrm{CO}_{2}$ as raw-materials, are simulated and compared in the present study. In the first case the intermediate step is the dry methane reforming (DMR) while in the second case the intermediate step is steam methane reforming (SMR). The syngas obtained is furthermore converted to methanol. Beside the transformation of COG into methanol, the present study deals also with the $\mathrm{CO}_{2}$ emissions reduction, the $\mathrm{CO}_{2}$ generated in the COG combustion is captured using amine based gas-liquid absorption technology (e.g. methyl diethanolamine - MDEA)). ChemCAD process flowmodelling software was used as a tool to produce $250 \mathrm{t} /$ day of methanol with purities higher than $99 \%$. The results showed that the most advantageous technological route of $\mathrm{COG}$ and $\mathrm{CO}_{2}$ utilization is $\mathrm{DMR}$, in which, a lower quantity of raw material $(\mathrm{COG})$ and lower number of equipment is required to obtain the same amount of final product.
\end{abstract}

Keywords: Coke Oven Gas, Process Modelling and Simulation, Methanol production, Technical evaluation.

\section{INTRODUCTION}

Methanol is an important raw material synthetized in large quantities in the chemical industry. It is an important material in the production of various chemical solvents, antifreeze and fuels. One of the most common uses of methanol is in the formaldehyde production. Formaldehyde is further used in the production of plastics, including those for construction, car paints, explosives or as a preservative for organisms in biological laboratories. Other

\footnotetext{
a Department of Chemical Engineering Babeş-Bolyai University, Faculty of Chemistry and Chemical Engineering, 11 Arany Janos str., RO-400028, Cluj-Napoca, Romania

*Corresponding author letitiapetrescu@chem.ubbcluj.ro
} 
substances using methanol as a raw material / intermediate are: acetic acid, methyl tert-butyl ether (MTBE), dimethyl ether (DME), methylamine, dimethyl carbonate (DMC), chloromethane. Besides its applications in the chemical and power industry, methanol attracted attention through its potential for use in the automotive industry, where it can be used as a fuel or it can lead to other fuels generation (i.e. biodiesel). Storing energy in the form of methanol could put an end to fossil fuel dependence, transforming carbon dioxide into a raw material for an economy based on methanol. This status is expected to last in the near future or even to improve it in order to transform it in a central participant in the worldwide economic landscape [1]. For these reasons, every improvement to methanol production process, in terms of energy savings, optimization, and minimization of its environmental impact has potential to promote relevant economic progress.

Coke oven gas (COG), a by-product of the coking process, can be used in effectively reducing the $\mathrm{CO}_{2}$ emissions caused by the steel industry. The production of methanol from COG-derived syngas has been investigated in the last period due to its practicality to obtain a liquid fuel instead of a gaseous product as well as to the recent interest in methanol over the past years [2]. The $\mathrm{CO}_{2}$ emissions reduction in the steel industry can also be performed through transforming COG into valuable products such as synthesis gas, hydrogen or methanol [3]. The process to transform COG to methanol is quite complex. The COG has a complex composition at the exit of the coke oven. It suffers several transformations in order to be converted into synthesis gas and furthermore to methanol. Firstly, the COG is cooled to remove pitch, which may form deposits on the gas lines, and then the $\mathrm{NH}_{3}$, $\mathrm{H}_{2} \mathrm{~S}$, benzene, toluene and xylene are removed from the COG. Chemically speaking COG has the following composition: $\mathrm{H}_{2} 55-60 \%$; $\mathrm{CH}_{4} 23-27 \%$; $\mathrm{CO} 5-8 \% ; \mathrm{N}_{2} 3-6 \% ; \mathrm{CO}_{2} 2 \%$. Traces of other hydrocarbons can also be present in the COG. The high calorific value of COG (e.g. $\left.17-18 \mathrm{MJ} / \mathrm{m}^{3}\right)$ is due to the substances from its composition: $\mathrm{H}_{2}, \mathrm{CH}_{4}, \mathrm{CO}, \mathrm{C}_{2} \mathrm{H}_{6}$.

Dry methane reforming (DMR) is a technology that converts two stable molecules, $\mathrm{CH}_{4}$ and $\mathrm{CO}_{2}$, into syngas. The process occurs at $700-$ $900^{\circ} \mathrm{C}$, at one atmosphere pressure or lower, using $\mathrm{Ni}, \mathrm{Rh}$ and $\mathrm{Ru}$ catalysts. It is considered to be an effective method for methanol synthesis, due to the possibility of obtaining an optimal $\mathrm{H}_{2} / \mathrm{CO}$ ratio in a single step, as long as the reaction takes place under stoichiometric conditions of $\mathrm{CH}_{4}$ and $\mathrm{CO}_{2}$. In addition, the process involves partial recycling of $\mathrm{CO}_{2}$, half of the carbon dioxide produced by the system being recycled. COG-DMR is investigated as a first option in the present study [4].

The most common way of obtaining methanol is through methane steam reforming (SMR). In the present study, the methane used for methanol generation comes from COG produced in a steel plant, so COG-SMR is 
considered as a second option. The conversion of COG into synthetic natural gas (SNG) is an efficient method to supply the high demand for natural gas on the market. The natural gas is a non-renewable energy source with a heat capacity between 20.1 and $38.26 \mathrm{MJ} / \mathrm{m}^{3}$ and it is not accessible in the long term. The SNG can be used in the chemical, energetic and transportation industries. Compared to the equivalent coal mass, the natural gas use reduces carbon dioxide emissions by approximately $40 \%$. COG is too rich in hydrogen to be used in the methanation reaction for producing SNG. The $\left(\mathrm{H}_{2}-\mathrm{CO}_{2}\right) /$ $\left(\mathrm{CO}+\mathrm{CO}_{2}\right)$ ratio in the $\mathrm{COG}$ is between 5 and 6 , the optimum value for the methanation being approximately 3 a high quantity of hydrogen remaining unconverted. The various studies on the technologies where an additional carbon source is needed revealed that, the use of an internal carbon source, produced within the system, instead of using an external gas source, can be a convenient solution to solve this problem. A considerable amount of carbon dioxide results from the combustion of coke oven gas for heat generation. This carbon dioxide is separated and reintroduced into the process using the gasliquid absorption (e.g. MDEA) [5]. The SNG obtained is further used in the methanol production process, using syngas as an intermediary product.

As already mentioned, two different methods of obtaining methanol are presented and compared in the present work (see Figure 1):

- DRM using $\mathrm{COG}$ and $\mathrm{CO}_{2}$ as raw materials and

- SMR, with SNG as a raw material for SMR. SNG is obtained through COG methanation and $\mathrm{CO}_{2}$ recycling.

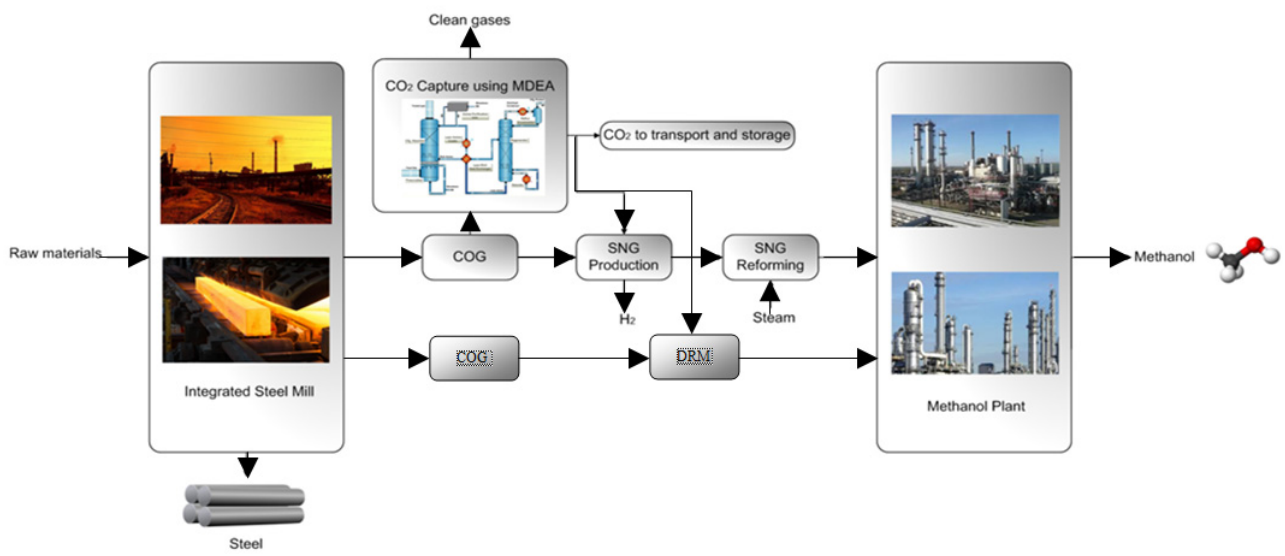

Figure 1. Methanol production from COG

The novelty of the present work consists on the technological comparison of the above mentioned technologies for methanol synthesis using $\mathrm{COG}$ and $\mathrm{CO}_{2}$ as raw-materials. 


\section{RESULTS AND DISCUSSION}

The cases investigated in the present work with their correspondent sub-processes are presented in Table 1.

Table 1. Cases investigated and their correspondent sub-processes

\begin{tabular}{|c|l|}
\hline Case Name & \multicolumn{1}{c|}{ Sub-process considered } \\
\hline \multirow{3}{*}{ Case $A$} & COG combustion \\
\cline { 2 - 2 } & $\mathrm{CO}_{2}$ capture using amine based gas-liquid absorption (i.e. MDEA) \\
\cline { 2 - 2 } & DMR for syngas generation \\
\cline { 2 - 2 } & Methanol synthesis from syngas \\
\hline Case $B$ & $\mathrm{COG}$ combustion \\
\hline & $\mathrm{CO}_{2}$ capture using amine based gas-liquid absorption (i.e. MDEA) \\
\hline & SNG production \\
\hline & SMR of SNG for syngas generation \\
\hline & Methanol synthesis from syngas \\
\hline
\end{tabular}

A schematic representation of the two cases under study is illustrated in Figure 2 and Figure 3 under EXPERIMENTAL SECTION. The main streams for Case $A$ are reported in Table 2.

Table 2. Main inputs and outputs for syngas production (Case A)

\begin{tabular}{|c|c|c|c|c|c|}
\hline \multirow[t]{2}{*}{ Parameters } & \multirow{2}{*}{$\begin{array}{l}\text { Unit of } \\
\text { measure }\end{array}$} & \multicolumn{4}{|c|}{ Streams } \\
\hline & & COG & $\begin{array}{c}\mathrm{CO}_{2} \text { from } \\
\mathrm{CO}_{2} \text { capture } \\
\text { unit }\end{array}$ & $\begin{array}{c}\text { Before } \\
\text { DRM }\end{array}$ & $\begin{array}{l}\text { After } \\
\text { DRM }\end{array}$ \\
\hline Pressure & atm & 0.98 & 0.98 & 0.98 & 0.98 \\
\hline Temperature & ${ }^{\circ} \mathrm{C}$ & 25 & 35 & 980 & 1000 \\
\hline Vapour fraction & - & 1 & 1 & 1 & 1 \\
\hline Liquid fraction & - & 0 & 0 & 0 & 0 \\
\hline \multicolumn{6}{|l|}{$\begin{array}{l}\text { Component } \\
\text { mole flow-rate }\end{array}$} \\
\hline $\begin{array}{l}\text { Carbon } \\
\text { Monoxide }\end{array}$ & $\mathrm{kmol} / \mathrm{h}$ & 53.95 & 0.00 & 32.46 & 327.55 \\
\hline Hydrogen & & 535.94 & 0.00 & 324.60 & 613.00 \\
\hline Carbon dioxide & & 27.25 & 133.77 & 150.28 & 1.07 \\
\hline Water & & 0.00 & 0.06 & 0.06 & 3.41 \\
\hline Nitrogen & & 45.41 & 0.38 & 27.89 & 27.89 \\
\hline Methane & & 245.46 & 0.00 & 148.54 & 2.66 \\
\hline Methanol & & 0.00 & 0.00 & 0 & 0.00 \\
\hline Total flow-rate & $\mathrm{kmol} / \mathrm{h}$ & 907.82 & 134.23 & 683.83 & 975.58 \\
\hline Total flow-rate & $\mathrm{kg} / \mathrm{h}$ & 8997.99 & 5899.79 & 11343.09 & 11343.09 \\
\hline
\end{tabular}


As noticed from Table 2, starting from $907.82 \mathrm{kmol} / \mathrm{h}$ of $\mathrm{COG}$ and $134.23 \mathrm{kmol} / \mathrm{h}$ of $\mathrm{CO}_{2}$ captured a molar flow-rate of $975.58 \mathrm{kmol} / \mathrm{h}$ gaseous stream is obtained in the DRM. The DMR stream has a high content of hydrogen (e.g. $613.00 \mathrm{kmol} / \mathrm{h}$ ) and CO (e.g. $327.55 \mathrm{kmol} / \mathrm{h}$ ). Small traces of $\mathrm{N}_{2}, \mathrm{CO}_{2}, \mathrm{CH}_{4}$ and $\mathrm{CO}_{2}$ can be also found in the outlet of DMR. This stream is furthermore sent to methanol synthesis step. The main inputs and outputs streams for methanol production using DRM as intermediary step are presented in Table 3.

Table 3. Main inputs and outputs for methanol production (Case A)

\begin{tabular}{|c|c|c|c|c|c|}
\hline \multirow[t]{2}{*}{ Parameters } & \multirow{2}{*}{$\begin{array}{l}\text { Unit of } \\
\text { measure }\end{array}$} & \multicolumn{4}{|c|}{ Streams } \\
\hline & & After DRM & $\begin{array}{l}\text { Before } \\
\text { methanol } \\
\text { synthesis }\end{array}$ & $\begin{array}{c}\text { After } \\
\text { methanol } \\
\text { synthesis }\end{array}$ & $\begin{array}{c}\text { Main } \\
\text { product }\end{array}$ \\
\hline Pressure & atm & 0.98 & 107.08 & 106.1 & 0.98 \\
\hline Temperature & ${ }^{\circ} \mathrm{C}$ & 1000 & 267 & 267 & 64.00 \\
\hline Vapour fraction & - & 1 & 1 & 1 & 1 \\
\hline Liquid fraction & - & 0 & 0 & 0 & 0 \\
\hline $\begin{array}{l}\text { Component } \\
\text { mole flow-rate }\end{array}$ & & & & & \\
\hline $\begin{array}{l}\text { Carbon } \\
\text { Monoxide }\end{array}$ & $\mathrm{kmol} / \mathrm{h}$ & 327.55 & 499.35 & 179.77 & 0.01 \\
\hline Hydrogen & & 613.00 & 1392.61 & 736.25 & 0.03 \\
\hline Carbon dioxide & & 1.07 & 33.68 & 27.96 & 0.02 \\
\hline Water & & 3.41 & 0.19 & 5.92 & 0.34 \\
\hline Nitrogen & & 27.89 & 1338.08 & 1338.08 & 0.03 \\
\hline Methane & & 2.66 & 18.30 & 18.30 & 0.002 \\
\hline Methanol & & 0.00 & 4.44 & 329.76 & 325.09 \\
\hline Total flow-rate & $\mathrm{kmol} / \mathrm{h}$ & 975.58 & 3286.69 & 2636.05 & 325.58 \\
\hline Total flow-rate & $\mathrm{kg} / \mathrm{h}$ & 11343.09 & 56201.58 & 56201.58 & 10425.88 \\
\hline
\end{tabular}

The gaseous stream obtained in the DMR (e.g. $975.58 \mathrm{kmol} / \mathrm{h}$ ) is mixed with a recycled stream coming from methanol purification section. As noticed from Table 3, the inlet of the methanol reactor is about 3286.69 $\mathrm{kmol} / \mathrm{h}$. The ratio between $\mathrm{H}_{2}$ and $\mathrm{CO}$ at the inlet of the reactor is around 3 . $\mathrm{CO}$ and $\mathrm{H}_{2}$ conversion in the methanol reactor is higher than $45 \%$, more exactly $47.13 \%$. A quantity of $325.58 \mathrm{kmol} / \mathrm{h}$ of methanol was produced in the above presented process. 
The main inputs and outputs derived from process modeling and simulation in the second option investigated (Case $B$ ) are summarized in Table 4.

Table 4. Main inputs and outputs for SNG production (Case B)

\begin{tabular}{|c|c|c|c|c|c|}
\hline \multirow[t]{2}{*}{ Parameters } & \multirow{2}{*}{$\begin{array}{c}\text { Unit of } \\
\text { measure }\end{array}$} & \multicolumn{4}{|c|}{ Streams } \\
\hline & & COG & $\begin{array}{c}\mathrm{CO}_{2} \text { from } \\
\mathrm{CO}_{2} \\
\text { capture } \\
\text { unit }\end{array}$ & $\begin{array}{c}\text { After } \\
\text { methanat } \\
\text { ion }\end{array}$ & $\begin{array}{c}\text { SNG } \\
\text { after } \\
\text { purifica } \\
\text { tion }\end{array}$ \\
\hline Pressure & atm & 0.98 & 0.98 & 23.50 & 39.50 \\
\hline Temperature & ${ }^{\circ} \mathrm{C}$ & 25 & 35 & 35 & 400 \\
\hline Vapour fraction & - & 1 & 1 & 0.65 & 1 \\
\hline Liquid fraction & - & 0 & 0 & 0.35 & 0 \\
\hline \multicolumn{6}{|l|}{$\begin{array}{l}\text { Component mole } \\
\text { flow-rate }\end{array}$} \\
\hline Carbon Monoxide & \multirow[t]{7}{*}{$\mathrm{kmol} / \mathrm{h}$} & 60.94 & 0.00 & 0.00 & 0.00 \\
\hline Hydrogen & & 596.30 & 0,00 & 7.17 & 0.00 \\
\hline Carbon dioxide & & 30.32 & 59.88 & 0,00 & 0.00 \\
\hline Water & & 0.00 & 0.03 & 221.87 & 0.00 \\
\hline Methane & & 272.88 & 0.00 & 366.13 & 366.02 \\
\hline Nitrogen & & 50.53 & 0.19 & 42.72 & 19.22 \\
\hline Oxygen & & 0.00 & 0.005 & 0.00 & 0.00 \\
\hline Total flow-rate & $\mathrm{kmol} / \mathrm{h}$ & 1010.68 & 60.10 & 637.90 & 385.25 \\
\hline Total flow-rate & $\mathrm{kg} / \mathrm{h}$ & 10028.55 & 2641.26 & 11082.21 & 6410.86 \\
\hline
\end{tabular}

As noticed from Table 4, starting from $1010.68 \mathrm{kmol} / \mathrm{h}$ of $\mathrm{COG}$ and $60.10 \mathrm{kmol} / \mathrm{h}$ of $\mathrm{CO}_{2}$ a quantity of $385.25 \mathrm{kmol} / \mathrm{h}$ of SNG was obtained. A total conversion of COG to SNG was considered. This high conversion leads to a high purity SNG (e.g. 95\% mole fraction). The SNG stream obtained from COG is furthermore used in methanol production. The main inputs and outputs streams for methanol production from SNG are presented in Table 5.

As reported in Table 5, a flow-rate of $385.25 \mathrm{kmol} / \mathrm{h}$ of SNG is sent to the SMR for syngas production. SNG is converted into syngas using about $1004.10 \mathrm{kmol} / \mathrm{h}$ of steam. A flow-rate of $2072.86 \mathrm{kmol} / \mathrm{h}$ syngas is obtained. This stream is mixed with some recycled stream coming from methanol purification section. The flow-rate of the recycled stream is $348.44 \mathrm{kmol} / \mathrm{h}$. The mixed stream is sent to methanol synthesis reactor. $\mathrm{CO}, \mathrm{CO}_{2}$ and $\mathrm{H}_{2}$ are transformed into methanol, which is furthermore separated using a flash and a distillation column. The final flow-rate of methanol is $327.71 \mathrm{kmol} / \mathrm{h}$, as noticed from Table 5 . 
Table 5. Main inputs and outputs for methanol production (Case $B$ )

\begin{tabular}{|c|c|c|c|c|c|}
\hline \multirow[t]{2}{*}{ Parameters } & \multirow{2}{*}{$\begin{array}{l}\text { Unit of } \\
\text { measure }\end{array}$} & \multicolumn{4}{|c|}{ Streams } \\
\hline & & SNG & $\begin{array}{l}\text { After } \\
\text { reforming } \\
\text { reactor }\end{array}$ & $\begin{array}{c}\text { After } \\
\text { methanol } \\
\text { synthesis }\end{array}$ & $\begin{array}{c}\text { Main } \\
\text { product }\end{array}$ \\
\hline Pressure & atm & 39.50 & 38 & 107.5 & 0.98 \\
\hline Temperature & ${ }^{\circ} \mathrm{C}$ & 400 & 1000 & 267 & 64.49 \\
\hline Vapour fraction & - & 1 & 1 & 1 & 1 \\
\hline Liquid fraction & - & 0 & 0 & 0 & 0 \\
\hline $\begin{array}{l}\text { Component mole } \\
\text { flow-rate }\end{array}$ & & & & & \\
\hline Carbon Monoxide & $\mathrm{kmol} / \mathrm{h}$ & 0.00 & 261.18 & 143.60 & $2 * 10^{-3}$ \\
\hline Carbon dioxide & & 0.00 & 805.87 & 348.23 & 0.05 \\
\hline Hydrogen & & 0.00 & 1105.83 & 15570.88 & 0.10 \\
\hline Nitrogen & & 19.22 & 19.22 & 34.07 & $2 * 10^{-4}$ \\
\hline Methane & & 366.02 & 24.27 & 1111.38 & 0.03 \\
\hline Water & & 0.00 & 581.77 & 80.72 & 2.44 \\
\hline Methanol & & 0.00 & 0.00 & 331.91 & 325.09 \\
\hline Total flow-rate & $\mathrm{kmol} / \mathrm{h}$ & 385.25 & 2072.86 & 17636.87 & 327.71 \\
\hline Total flow-rate & $\mathrm{kg} / \mathrm{h}$ & 6410.86 & 24499.58 & 81670.13 & 10463.54 \\
\hline
\end{tabular}

The main technical key performance indicators obtained in the two investigated cases are reported in Table 6.

Table 6. Comparative results obtained in Case $A$ and Case $B$

\begin{tabular}{|l|c|c|c|}
\hline \multicolumn{1}{|c|}{ Parameter } & Component & Case $A$ & Case $B$ \\
\hline Raw-material (kmol/h) & $\mathrm{COG}$ & 907.82 & 1010.68 \\
\cline { 2 - 4 } & $\mathrm{CO}_{2}$ & 134.23 & 60.10 \\
\hline Final product (t/day) & $\mathrm{CH}_{3} \mathrm{OH}$ & 250 & 250 \\
\hline MeOH (wt.\%) & & 99.92 & 99.55 \\
\hline $\mathrm{CO}_{2}$ capture rate (\%) & & 84.53 & 84.77 \\
\hline $\begin{array}{l}\text { No. of unit operations } \\
\text { involved in the whole process }\end{array}$ & & 48 & 66 \\
\hline Energy consumption (MW) & & 13.50 & 14.20 \\
\hline $\mathrm{CO}_{2}$ emissions (kg/h) & 48.76 & 395.20 \\
\hline
\end{tabular}

As presented in Table 6, different quantities of raw-materials (i.e. $\mathrm{COG}$ and $\mathrm{CO}_{2}$ ) are used in the two investigated technologies in order to obtain the same quantity of methanol (e.g. $250 \mathrm{t} /$ day). Higher quantities of COG are used in Case $B$ compared to Case $A$ (e.g. $1010.68 \mathrm{kmol} / \mathrm{h}$ vs. $907.82 \mathrm{kmol} / \mathrm{h}$ ). The $\mathrm{CO}_{2}$ flow-rate is two times lower in Case $B$ compared to 
Case A. High methanol purities are obtained in both cases. Almost pure methanol is obtained in Case $A$. The $\mathrm{CO}_{2}$ capture rates are about $85 \%$ in both cases. The energy consumption in Case $A$ is lower compared to the energy consumption used in Case $B$ (e.g. $13.50 \mathrm{MW}$ vs. 14.20 MW). The number of unit operations involved in Case $A$ is lower compared to Case $B$ (e.g. 48 units operations vs. 66 units operations). The $\mathrm{CO}_{2}$ emissions in Case $A$ are about eight times lower compared to the $\mathrm{CO}_{2}$ emissions from Case $B$.

\section{CONCLUSIONS}

The aim of the present paper was to compare, from technological point of view, two processes for methanol production using $\mathrm{COG}$ and $\mathrm{CO}_{2}$ as raw materials. In order to reach the proposed goal process flow-modeling tools (i.e. ChemCAD process simulator software) was used. The plant capacity in each case was set to $250 \mathrm{t} /$ day. The simulations results are in accordance with the data from the scientific literature, fact which was demonstrated by models validation.

From a technological point of view, the most advantageous route, between the two investigated cases, is methanol production from COG through DMR - Case $A$, in which a lower quantity of COG is required to obtain the same amount of final product. The other solution investigated was methanol production from COG through SMR, denoted as Case $B$.

The two cases are compared using various key performance indicators. Less unit operations are involved in Case $A$ compared to Case $B$. Considering the $\mathrm{CO}_{2}$ emissions released in the two investigated cases it can be concluded that these emissions are eight times less in Case $A$ compared to Case $B$. The technologies of methanol production from COG are in line with the current environmental problems, due to the following two aspects:1) they valorize a by-product of steel plants (i.e. COG), turning it into valuable products (SNG and methanol); 2) they reduce the $\mathrm{CO}_{2}$ released into the atmosphere.

It can be concluded that methanol production from $\mathrm{COG}$ and $\mathrm{CO}_{2}$ capture through DMR offers several advantages.

\section{EXPERIMENTAL SECTION GENERAL PRESENTATION}

Figure 2 illustrates the block flow diagram for Case $A$. The first intermediate step considered in this case is the DRM. The COG is mixed with a $\mathrm{CO}_{2}$ stream which was previously generated during the total combustion of 
some COG and captured using amine based gas-liquid absorption technology (using MDEA as a solvent). The methane-carbon dioxide mixture is introduced into the catalytic reforming reactor leading to syngas. The obtained syngas is cooled, compressed and sent to methanol synthesis step, where $\mathrm{CO}, \mathrm{CO}_{2}$ and $\mathrm{H}_{2}$ are converted to methanol. The final step is the methanol separation. A methanol stream having a flow-rate of $250 \mathrm{t} /$ day and a purity of $99.92 \%$ is obtained after the separation step.

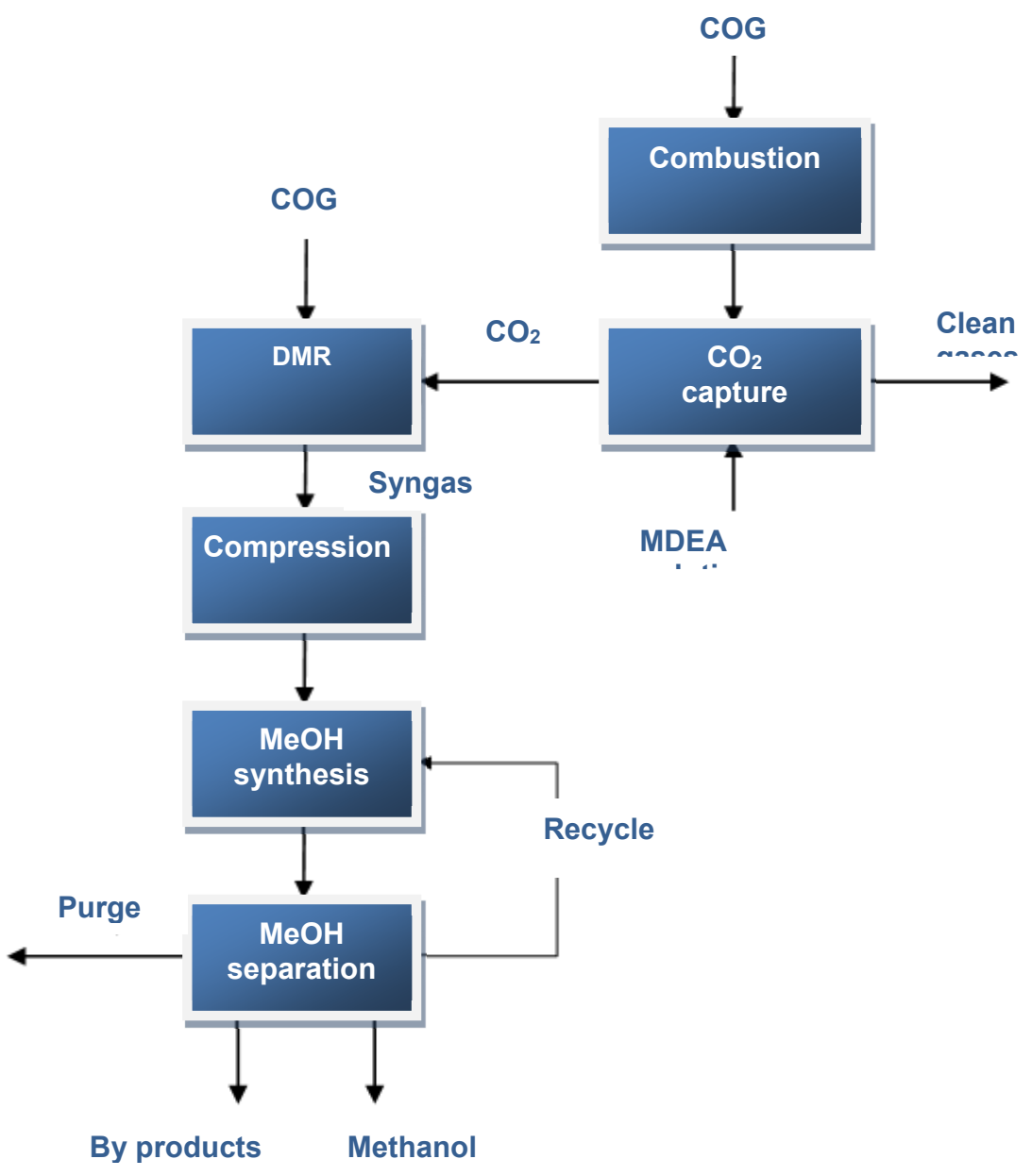

Figure 2. Simplified block flow diagram for Case $A$ 


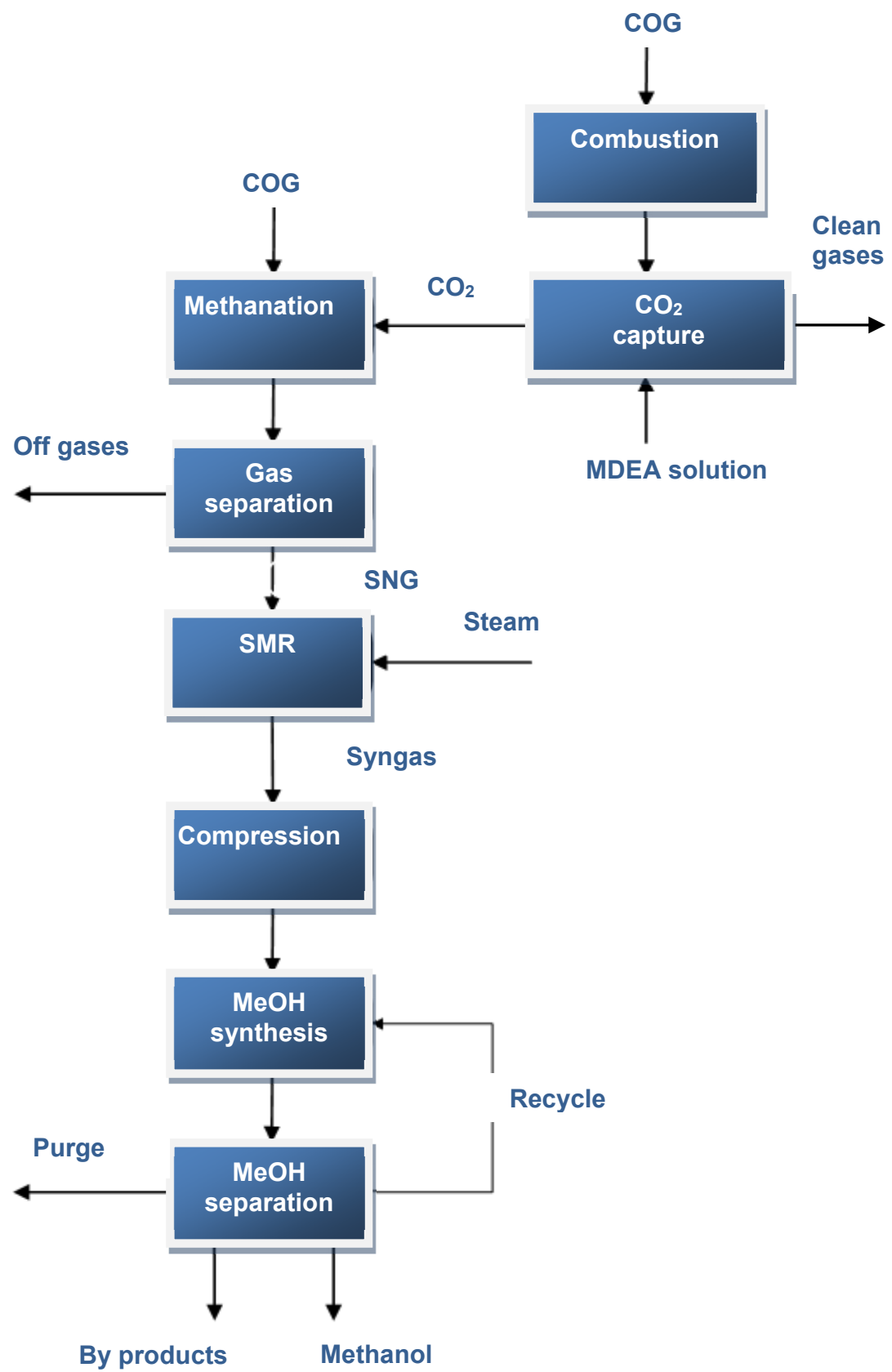

Figure 3. Simplified block flow diagram for Case $B$ 
Figure 3 shows the simplified block diagram for Case $B$. COG is the raw material also used in this case. It is divided into two streams, one part is sent to the combustion chamber and the rest to the methanation step. The combustion gases are sent to a $\mathrm{CO}_{2}$ capture unit. As in the previous case, $\mathrm{CO}_{2}$ capture is based on gas-liquid absorption. MDEA is the solvent used for $\mathrm{CO}_{2}$ removal. After separation, pure $\mathrm{CO}_{2}$ is reintroduced into the system together with the COG stream. The $\mathrm{COG}-\mathrm{CO}_{2}$ gas mixture obtained is sent to the methanation unit which leads to a rich $\mathrm{CH}_{4}$ stream. This is furthermore separated in a stream containing $91.59 \% \mathrm{CH}_{4}$ called also SNG. Furthermore, SNG is fed to a SMR unit where, using steam, $\mathrm{CH}_{4}$ is converted to syngas. The syngas is sent to the cooling unit, compressed and sent to the methanol synthesis step. The result of this step is a methanol rich product, which is purified in a separation system. The same productivity of methanol (e.g. 250 $\mathrm{t} /$ day) is obtained in Case $B$. Methanol purity in this case study is $99.55 \%$.

The reactions tacking place in the combustion step are $\left(R_{1}-R_{3}\right)$ presented below [5]:

$$
\begin{aligned}
& \left(R_{1}\right): \mathrm{H}_{2}+0.5 \mathrm{O}_{2} \rightarrow \mathrm{H}_{2} \mathrm{O} \\
& \left(R_{2}\right): \mathrm{CH}_{4}+2 \mathrm{O}_{2} \rightarrow \mathrm{CO}_{2}+2 \mathrm{H}_{2} \mathrm{O} \\
& \left(R_{3}\right): 2 \mathrm{CO}+\mathrm{O}_{2} \rightarrow 2 \mathrm{CO}_{2}
\end{aligned}
$$

$$
\begin{aligned}
& \Delta H_{298 \mathrm{~K}}=-285.83 \mathrm{~kJ} / \mathrm{mol} \\
& \Delta H_{298 \mathrm{~K}}=-890.36 \mathrm{~kJ} / \mathrm{mol} \\
& \Delta H_{298 \mathrm{~K}}=-566 \mathrm{~kJ} / \mathrm{mol}
\end{aligned}
$$

All reactions are exothermic, generating heat for the process in which coal is turned into coke. The process temperature varies between 1250 $1300^{\circ} \mathrm{C}$. In general, the excess air coefficient is between $1.2-1.3$. For the simulation of the process, the air coefficient was set to 1.25 . The reactions take place completely, all the components $\left(\mathrm{H}_{2}, \mathrm{CH}_{4}, \mathrm{CO}\right)$ being transformed into water and carbon dioxide.

The reactions occurring in the methanation step are $\left(R_{4}-R_{6}\right)[5]$ :

$$
\begin{aligned}
& \left(R_{4}\right): \mathrm{CO}+3 \mathrm{H}_{2} \rightarrow \mathrm{CH}_{4}+\mathrm{H}_{2} \mathrm{O} \\
& \left(R_{5}\right): \mathrm{CO}_{2}+4 \mathrm{H}_{2} \rightarrow \mathrm{CH}_{4}+2 \mathrm{H}_{2} \mathrm{O} \\
& \left(R_{6}\right): \mathrm{CO}+\mathrm{H}_{2} \mathrm{O} \rightarrow \mathrm{CO}_{2}+\mathrm{H}_{2}
\end{aligned}
$$

$$
\begin{aligned}
& \Delta H_{298 K}=-206 \mathrm{~kJ} / \mathrm{mol} \\
& \Delta H_{298 K}=-165 \mathrm{~kJ} / \mathrm{mol} \\
& \Delta H_{298 K}=-41 \mathrm{~kJ} / \mathrm{mol}
\end{aligned}
$$

The first two reactions are strongly exothermic, and the third reaction occurs only when the carbon monoxide concentration is low and the hydrogen is in excess. In the industry, the catalysts used for the methane process are nickel-based. They maintain high activity in a wide temperature range $\left(200-700^{\circ} \mathrm{C}\right)$ and can convert almost $100 \%$ of CO and over $98 \%$ of the $\mathrm{CO}_{2}$. 
The reactions taking place in the $\mathrm{CO}_{2}$ capture section are $\left(R_{7}-R_{10}\right)[5]$ :

$\left(R_{7}\right): M D E A H^{+}+\mathrm{H}_{2} \mathrm{O}=\mathrm{MDEA}+\mathrm{H}_{3} \mathrm{O}^{+}$

$\left(\mathrm{R}_{8}\right): \mathrm{CO}_{2}+\mathrm{OH}^{-}=\mathrm{HCO}_{3}^{-}$

(R9): $\mathrm{HCO}_{3}^{-}+\mathrm{H}_{2} \mathrm{O}=\mathrm{H}_{3} \mathrm{O}^{+}+\mathrm{CO}_{3}{ }^{2-}$

(R $\left(R_{10}\right): 2 \mathrm{H}_{2} \mathrm{O}=\mathrm{H}_{3} \mathrm{O}^{+}+\mathrm{OH}^{-}$

The reaction considered for DRM is $R_{11}[2,3]$ :

$\left(R_{11}\right): \mathrm{CH}_{4}+\mathrm{CO}_{2} \leftrightarrow 2 \mathrm{H}_{2}+2 \mathrm{CO}$

$\Delta H_{298 K}=247.30 \mathrm{~kJ} / \mathrm{mol}$

The interest for DRM technology is due to the low energy consumption, compared to the SMR, because it uses two greenhouse gases: $\mathrm{CO}_{2}$ and $\mathrm{CH}_{4}$ generating valuable products. $\mathrm{CO}_{2}$ reforming allows the production of a synthesis gas with low $\mathrm{H}_{2} / \mathrm{CO}$ ratios, theoretically $1 / 1$.

The reaction considered in $\mathrm{SMR}$ is $R_{12}[2,3]$ :

$\left(R_{12}\right): \mathrm{CH}_{4}+\mathrm{H}_{2} \mathrm{O} \rightarrow 3 \mathrm{H}_{2}+\mathrm{CO} \quad \Delta H_{298 K}=206.20 \mathrm{~kJ} / \mathrm{mol}$

SMR is currently the main process for obtaining synthesis gas. This involves the catalyzed reaction between methane and steam to obtain the synthesis gas with an increased $\mathrm{H}_{2}$ / CO ratio, the optimum value being $3 / 1$. $[2,3]:$

The reactions taking place in the methanol synthesis are $\left(R_{13}-R_{15}\right)$

$\left(R_{13}\right): \mathrm{CO}+2 \mathrm{H}_{2} \leftrightarrow \mathrm{CH}_{3} \mathrm{OH}$

$\Delta H_{298 K}=-90.79 \mathrm{~kJ} / \mathrm{mol}$

(R $\left(R_{14}\right): \mathrm{CO}_{2}+3 \mathrm{H}_{2} \leftrightarrow \mathrm{CH}_{3} \mathrm{OH}+\mathrm{H}_{2} \mathrm{O}$

$\Delta H_{298 K}=-49.79 \mathrm{~kJ} / \mathrm{mol}$

$\left(R_{15}\right): \mathrm{CO}_{2}+\mathrm{H}_{2} \leftrightarrow \mathrm{CO}+\mathrm{H}_{2} \mathrm{O}$

$\Delta H_{298 K}=41.00 \mathrm{~kJ} / \mathrm{mol}$

All of these reactions are reversible and depend on the reaction conditions. Methanol synthesis reactions are exothermic and maximum conversion is achieved under high pressure and low temperature.

\section{DETAILS ON PROCESS MODELLING AND SIMULATION}

The two cases have been modelled using ChemCAD process simulator developed by Chemstations [6]. Case $A$ sub-processes have been listed in Table 1 and the assumptions used in process modelling and simulation are presented in Table 7. 
Table 7. Process modelling assumptions for Case $A$

\begin{tabular}{|c|c|}
\hline Case $A$ & Assumptions \\
\hline $\begin{array}{l}\text { Input data } \\
\text { specifications }\end{array}$ & $\begin{array}{l}\text { COG molar composition: } \\
\qquad \begin{array}{l}\mathrm{CO}=0.06 \\
\mathrm{H}_{2}=0.59 \\
\mathrm{CO}_{2}=0.03 \\
\mathrm{CH}_{4}=0.27 \\
\mathrm{~N}_{2}=0.05 \\
\text { COG temperature: } 25^{\circ} \mathrm{C} \\
\text { COG pressure: } 1 \mathrm{~atm}\end{array}\end{array}$ \\
\hline COG combustion & $\begin{array}{l}\text { Total combustion is considered. } \\
\text { Combustion temperature: } 1300^{\circ} \mathrm{C} \\
\text { Excess air is used for combustion. }\end{array}$ \\
\hline $\mathrm{CO}_{2}$ capture & $\begin{array}{l}\text { MDEA solution }(50 \% \text { wt. }) \text { is used for gas-liquid } \\
\text { absorption. } \\
\text { Absorption column: } 30 \text { trays. } \\
\text { Desorption column: } 10 \text { trays. }\end{array}$ \\
\hline DMR & $\begin{array}{l}\text { The DMR catalytic reforming reactor is operated at } \\
1000^{\circ} \mathrm{C} \text { and } 0.98 \mathrm{~atm} \text {. } \\
\text { The flow obtained is cooled to } 50^{\circ} \mathrm{C} \text {. }\end{array}$ \\
\hline Syngas compression & $\begin{array}{l}\text { After water removal and compression, the synthesis gas } \\
\text { reaches } 145^{\circ} \mathrm{C} \text { and } 29.6 \text { atm. The gas is furthermore } \\
\text { compressed to } 108.56 \text { atm. The compressor efficiency is } \\
75 \% \text {. }\end{array}$ \\
\hline Methanol synthesis & $\begin{array}{l}\text { The methanol synthesis reactor is operated at } 267^{\circ} \mathrm{C} \text { and } \\
107 \text { atm. } \\
\text { The pressure drop in the reactor is } 0.98 \mathrm{~atm} .\end{array}$ \\
\hline Methanol separation & $\begin{array}{l}\text { The methanol purification unit consists of two separators } \\
\text { whose resulting gaseous fluxes are compressed at } 108.56 \\
\text { atm and returned to the process. The compressors are } \\
\text { adiabatic and their efficiencies are } 75 \% \text {. The first separator } \\
\text { is operated at } 105 \text { atm and } 38^{\circ} \mathrm{C} \text {. The second separator is } \\
\text { operated at } 1.97 \text { atm and } 38^{\circ} \mathrm{C} \text {. The distillation column has } \\
42 \text { plates, the feed is made on plate } 27 \text {. The pressure at } \\
\text { the top of the column is } 0.98 \mathrm{~atm} \text {. }\end{array}$ \\
\hline
\end{tabular}

Case $B$ sub-processes have been listed in Table 1 and the assumptions used in process modelling and simulation are presented in Table 8. 
Table 8. Process modelling assumptions for Case $B$

\begin{tabular}{|c|c|}
\hline Case B & Assumptions \\
\hline $\begin{array}{l}\text { Input data } \\
\text { specifications }\end{array}$ & $\begin{array}{l}\text { COG molar composition: } \mathrm{CO}=0.06 ; \mathrm{H}_{2}=0.59 ; \\
\mathrm{CO}_{2}=0.03 ; \mathrm{CH}_{4}=0.27 ; \mathrm{N}_{2}=0.05 \\
\text { COG temperature: } 25^{\circ} \mathrm{C} \\
\text { COG pressure: } 1 \mathrm{~atm}\end{array}$ \\
\hline COG combustion & $\begin{array}{l}\text { Total combustion is considered. } \\
\text { Combustion temperature: } 1300^{\circ} \mathrm{C} \\
\text { Excess air is used for combustion. }\end{array}$ \\
\hline $\mathrm{CO}_{2}$ capture & $\begin{array}{l}\text { MDEA solution ( } 50 \% \text { wt.) is used for gas-liquid absorption. } \\
\text { Absorption column: } 30 \text { trays. } \\
\text { Desorption column: } 10 \text { trays. }\end{array}$ \\
\hline Methanation section & $\begin{array}{l}\text { Three reactors are used for this section. } \\
\text { The first reactor is operated at } 620^{\circ} \mathrm{C} \text {, the mixture obtained } \\
\text { being furthermore cooled to } 300^{\circ} \mathrm{C} \text {. } \\
\text { The second reactor is operated at } 300^{\circ} \mathrm{C} \text {, the mixture } \\
\text { obtained being subsequently cooled to } 240^{\circ} \mathrm{C} \text {. } \\
\text { The third reactor is operated at } 240^{\circ} \mathrm{C} \text {, the mixture obtained } \\
\text { then cooled to } 168^{\circ} \mathrm{C} \text {. } \\
\text { The gaseous product obtained by separation is rich in } \\
\text { hydrogen and methane gas. }\end{array}$ \\
\hline Gas separation & $\begin{array}{l}\text { SNG with composition } 95 \% \mathrm{CH}_{4} \text { and } 5 \% \mathrm{~N}_{2} \text { is obtained in } \\
\text { this section. }\end{array}$ \\
\hline SMR & $\begin{array}{l}\text { High pressure steam }\left(\mathrm{p}=118.4 \mathrm{~atm}, \mathrm{~T}=360^{\circ} \mathrm{C}\right) \text { is used in } \\
\text { the SMR. } \\
\text { The methane-steam mixture is preheated to } 870^{\circ} \mathrm{C} \text { before } \\
\text { being introduced into the reforming reactor. } \\
\text { The reforming reactor is a Gibbs type reactor, operating at } \\
1000^{\circ} \mathrm{C} \text { and } 37.5 \mathrm{~atm} \text {. }\end{array}$ \\
\hline Syngas compression & $\begin{array}{l}\text { The gas mixture leaving the reforming reactor is cooled and } \\
\text { compressed in two steps to the desired pressure of } 107 \\
\text { atm. } \\
\text { Compressors efficiencies are } 75 \% \text {. }\end{array}$ \\
\hline Methanol synthesis & $\begin{array}{l}\text { The methanol synthesis reactor is operated at } 267^{\circ} \mathrm{C} \text { and } \\
107 \mathrm{~atm} . \\
\text { The pressure drop in the reactor is } 0.98 \mathrm{~atm} .\end{array}$ \\
\hline Methanol separation & $\begin{array}{l}\text { The methanol purification unit consists of two separators } \\
\text { whose resulting gaseous fluxes are compressed at } 108.56 \\
\text { atm and returned to the process. The compressors are } \\
\text { adiabatic and their efficiencies are } 75 \% \text {. The first separator } \\
\text { is operated at } 105 \text { atm and } 38^{\circ} \mathrm{C} \text {. The second separator is } \\
\text { operated at } 1.97 \text { atm and } 38^{\circ} \mathrm{C} \text {. The distillation column has } \\
42 \text { plates, the feed is made on plate } 27 \text {. The pressure at the } \\
\text { top of the column is } 0.98 \text { atm. }\end{array}$ \\
\hline
\end{tabular}


The developed models were validated using literature date, the error between the proposed models and those found in the literature being less than $5 \%$.

A comparative simulation-literature study was performed for the main flows obtained in Case B in order to validate the SNG production model developed in ChemCAD. The data obtained for the SNG production is in accordance with those from the literature (see Table 9).

Table 9. Model validation for SNG production process

\begin{tabular}{|c|c|c|c|}
\hline \multirow{2}{*}{ Parameter } & \multirow{2}{*}{ Unit of measure } & \multicolumn{2}{|c|}{ SNG production } \\
\hline & & Present work & Literature [5] \\
\hline Pressure & atm & 19.70 & 19.73 \\
\hline Temperature & ${ }^{\circ} \mathrm{C}$ & 25 & 25 \\
\hline Vapour fraction & - & 1 & 1 \\
\hline Liquid fraction & - & 0 & 0 \\
\hline \multicolumn{4}{|l|}{ Composition } \\
\hline Carbon Monoxide & \multirow{7}{*}{ Mole fractions } & 0 & 0 \\
\hline Hydrogen & & 0 & 0 \\
\hline Carbon dioxide & & 0 & 0 \\
\hline Water & & 0 & 0 \\
\hline Methane & & 0.95 & 0.95 \\
\hline Nitrogen & & 0.05 & 0.05 \\
\hline Oxygen & & 0 & 0 \\
\hline
\end{tabular}

For methanol synthesis, the data obtained from process modelling and simulation was validated in comparison with scientific literature data (see Table 10).

Table 10. Model validation for methanol production process (Case $B$ )

\begin{tabular}{|c|c|c|c|}
\hline \multirow{2}{*}{ Parameter } & \multirow{2}{*}{ Unit of measure } & \multicolumn{2}{|c|}{ MeOH production } \\
\hline & & Simulation & Literature [7] \\
\hline Carbon Monoxide & \multirow{7}{*}{ Mole fractions } & 0.00 & 0.00 \\
\hline Hydrogen & & $3 \cdot 10^{-5}$ & 0.00 \\
\hline Carbon dioxide & & $1.45 \cdot 10^{-5}$ & 0.009 \\
\hline Water & & 0.007 & 0.001 \\
\hline Methane & & $9.07 \cdot 10^{-5}$ & 198 ppm \\
\hline Nitrogen & & $7.58 \cdot 10^{-5}$ & $727 \mathrm{ppm}$ \\
\hline Methanol & & 0.99 & 0.98 \\
\hline
\end{tabular}




\section{REFERENCES}

1. G.A. Olah, and G.K.S. Prakash. "Beyond oil and gas: the methanol economy", 2011, John Wiley \& Sons.

2. G. Bozzano, F. Manenti. Prog. Eneg Combust., 2016, 56, 71-105.

3. J.M. Bermúdez, A. Arenillas, R. Luque, J.A. Menéndez. Fuel Process. Technol., 2013, 110, 150-159.

4. J.M. Bermúdez, N. Ferrera-Lorenzo, S. Luque, A. Arenillas, Menéndez, J.A. Fuel Process. Technol., 2013, 115, 215-221.

5. Q. Yi, G. Wu, M. Gong, Y. Huang, J. Feng, Z. Hao, W. Li. Appl. Energ., 2017, 193, 149-16.

6. ChemCAD Chemical Process Simulation - Chemstations, Huston, USA, http://www.chemstations.com (accessed on April 2020).

7. W.L. Luyben. Ind. Eng. Chem. Res., 2010, 49, 6150-6163. 